$\xi=-1$

\title{
Halal Logo, Beauty Blogger \& Halal Marketing Package : Which One is the Most Influencing Factors that Lead into Purchase Decision on Halal Cosmetic
}

\author{
Telisiah Utami Putri \\ Doctor of Research in Management, BINUS University \\ *Corresponding author E-mail:putri.telisiah@gmail.com
}

\begin{abstract}
Halal cosmetic becomes more popular today, and soon or later shall be perceived as a necessity. Halal products themselves are identical with the presence of halal logo on the product or packaging, however does halal logo enough to stimulate consumer to choose a certain halal cosmetic brand?

Consumer nowadays are exposed with more options of communication from many brands, both digital and non-digital media are presented to today's consumer, in response to current situation manufacturer has to understand kind of media that might significantly affect their consumer behavior. In digital media the presence of beauty bloggers are started to get consumer's attention and suddenly become a new reference for seeking information of a new product, however the presence of convential halal marketing package is still undeniable, kind of models with hijab and Islamic message on the communication of is also considered play significant role in building consumer perceptions.

This study aims to find out whether halal logo, beauty blogger or conventional halal marketing package is the most significant factor to create consumer positive perception that will ultimately determine purchase decision to buy halal cosmetic products.

The study is conducted in Jakarta and Surabaya via on-line survey through WhatsApp mobile application to those active users of social media ages 20-50 y.o and using mass-market cosmetic. Mobile application is chosen in order to get spesific target respondents who are members of social media. Using structural questionnaire, up loaded digitally by using Google forms, that been delivered by using smartphone through WhatsApp mobile application within 1 week of field study.

Findings reveals if conventional halal marketing package is still more significant to create positive perception, followed with Halal logo and beauty blogger.
\end{abstract}

Keywords: Halal logo, beauty blogger, conventional halal marketing package, purchase decision

\section{Introduction}

Global market demand for cosmetic products halal continue to rise, in 2015 the value of the global market for cosmetics women to reach US \$ 23.4 billion and is expected in 2020 will reach US \$ 45 billion with a CAGR of $14.3 \%$, while the growth of the cosmetics market in Asia-Pacific region will experience growth of $11.8 \%$ from the period 2013-2018(1)

Although muslim is the major population in Indonesia and contribute significant affect to halal cosmetic market in Indonesia, supported by research conducted by the Pew Research Centre "The Future of the Global Muslim Population" - January 2011 (2) estimates that by 2030 Indonesia will occupy the 2 nd position of the largest Muslim population in the world, numbers of 238 million people. In fact that does not mean halal cosmetics will be devoted only to Muslim women, in practice, non-Muslim women consumers also become the target consumers for cosmetic manufacturers. For halal cosmetics manufacturer itself non-Muslim consumers are their potential target consumer, by taking the nonmuslim consumers as target market besides muslim consumers, halal cosmetic market becomes wider and has more possibility to greater business opportunities.
Along with the consumer awareness of halal cosmetic known as safe for health, halal cosmetic perceived provide guarantees for the safety, purity and healthy can become its own attractiveness to non-muslim consumer in Indonesia. Halal is no longer just purely religious issue. It is in the realm of business and trade, and it is becoming a global symbol for quality assurance and lifestyle (3). With the increasing demand for halal cosmetic particularly in Indonesia market, trigger cosmetic manufacturers to adapt to these changes, trying to make dedicated halal cosmetic product or register their existing products to the formal institutions authorized to issue halal certification and obtain halal logo are some part of the ways to be taken.

In addition besides talking about the product, cosmetics companies should also be very concerned about the communication media that will be used, currently some of the leading cosmetic brands using halal marketing package in the form of use of veiled models or communication content with Islamic sentences such as the mention of the word halal etc., the goal is none other than to create the perception of a halal product that is certainly expected to form a positive perception and ultimately strengthen consumer buying intention.

Advertising is the promotional arm of marketing. An alternative to conventional marketing is Islamic marketing. Islamic marketing is a 'differentiated wave' in marketing activities and consumption, 
because of its affiliation with Islamic faith, culture, heritage, and milieu, and role as a challenger to conventional marketing (4).

The conventional halal marketing package in this study is based on the phenomenon that exists in Indonesia, limited only to the use of Muslim women's dress models or hijabs and the use of Islamic language in communication content such as the phrase "halal" or "Alhamdulillah" on communication content.

Based on (5) Indonesia by 2016 has total population 259.1 million people, with internet active users 88.1 million, 79 million active social media users and 66 million active mobile social users, seeing this number definitely shown if social media is an important media for a cosmetic company to think and create communication to their target consumers.

As a part of digital marketing, a social network marketing through word-of-mouth effect is extremely powerful. People are likely to be affected by the decisions of their friends and colleagues (6). One of the Blogger involvement in social media is their review or writing, this output emphasize the important role of writing and referring product reviews in the internet such is blogosphere or online communities(7).

A beauty blogger makes beauty as the main theme in her blog that sometimes combined with a variety of other information such as lifestyle, fashion and make-up tutorial. The presence of beauty bloggers as a reference or referral for those who are looking for recommended cosmetic products. Through a variety of beauty product review ever attempted directly by beauty bloggers, they explain the strengths and weaknesses of a particular brand of cosmetic products.

Through the beauty product review article written by beauty bloggers, readers have knowledge of a variety of benefits to be gained from cosmetic products. Additionally, beauty blogger also recommends best brand cosmetic products and update price list as consideration for the reader before purchasing the product.

This study started from the basic concerns of cosmetic manufacturer to find out factors that leads consumer purchase decision on halal cosmetic from halal logo and marketing package.

This study take respondents of active women from age range 20 up to 50 years old both are muslim and non-muslim, users of mass-market cosmetic brand which is sold in Indonesia, the respondents are coming from 2 major cities Jakarta and Surabaya, the survey is conducted via on-line survey. The result of this study is expected to be a preliminary study used by cosmetic manufacturer to set up the most suitable communication strategy to be competitive in halal cosmetic market.

\section{Theoretical Framework}

This study uses Theory of reason action (8) The purpose of behavior is influenced some one's attitude toward the specific characteristics being considered and the subjective norm. Social pressure to perform the action. It consists of attitude, subjective norms, behavior.

Theory The behavioral plan became the theoretical foundation that later evolved into Theory of Plan Behavior (9)(10), the basis for the selection of Theory of plan behavior to support the decision to purchase halal cosmetics against other antecedents because the purchase decision in halal cosmetics is not included in impulse buying behavior, generally before purchasing cosmetics, consumers have first planned the choice of brand or type of cosmetic product they want to use or purchase.

The proposed framework for this research does not directly translate Theory of Plan Behavior, but Theory of Plan Behavior helps explain the way in which consumers have a belief or perception that is determined or influenced by the consumer's desire to engage in behavior or action, the most relevant component of the TPB is the attitude (Attitude).

The attitude that comes from belief (Belief) if halal cosmetics is better, in terms of the feelings of elements about halal cosmetics can provide positive emotions and thus create a feeling of security to the product and affect consumer behavior to the next stage which ultimately determines the decision to purchase halal cosmetics.

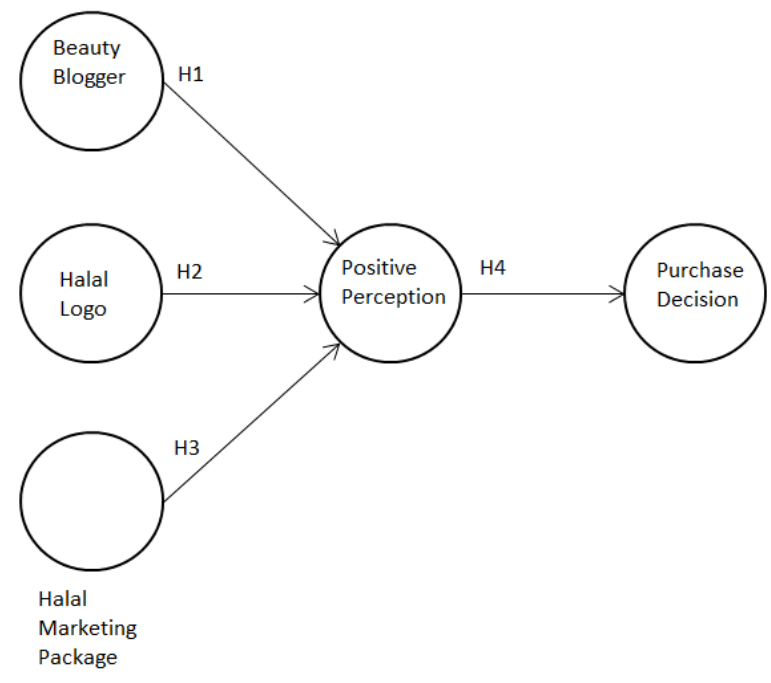

Figure 1: Research Model

\subsection{Beauty Blogger}

In cosmetic industry beauty blogger becomes more popular today, we often see ads in social media that use a beauty blogger in introducing a new product or new brand. Beauty blogger suddenly became instant celebrity liked by many fans . The ability of beauty bloggers in enganging her followers and influence the followers to what she does, likes, uses gives credits to the beauty blogger that eventually creating her high grade endorser.

Word of mouth is a powerful tool to influence people and can influence consumer buying behavior. According to (11) online word of mouth as "Every statement is positive or negative is made by potential customers, current customers or former customers about the product or company that has been disseminated to many people and agencies Through the internet ". Social media (Twitter, Facebook, LinkedIn, Pintrest, etc.) that connects people, also able to bring marketers into the wider society, as an active participant.

The use of celebrity models also signifies the actual presence of the creator of marketing (12). Online marketing communications, special, E-WOM, Online Communities and Online Advertising is effective in promoting the brand and products through the company's website and social media platforms (13).

Nowadays bloggers have also become a new phenomenon in the world of marketing, viral marketing through bloggers, especially beauty bloggers become the selling method, one of the most advanced today where an instant conversation in the web can make a product or brand became trending topics, in addition beauty blogger has the power of the masses to influence others because she has followers or fans. According to (14) WOMM that attempts to direct the discourses of bloggers may seem to have many similarities with the use of public relations or other forms of paid promotion.

One way for cosmetic brands to understand consumer needs and have access to customer feedback. No place lends itself to this task better than the website and social networks. They not only enable firms to develop their understanding of customer needs but also provide a huge opportunity for a firm to impact customers' purchase intentions, all the more as the internet and social networks keep growing (15).

In this variable the authors want to know more in how much influence the beauty blogger in building a positive perception of a brand cosmetic. By seeing the condition of how blogger gives influence towards consumer responses, this study is aimed to check the significant relation between beauty blooger in cosmetic 
industry towards creating positive perception that eventually lead to consumer decision to buy halal cosmetic.

H1 : There is significant relationship between beauty blogger and positive perception

\subsection{Halal Logo}

Having a Halal logo or certificate in today's globalized world is a must in order to cater for all Muslim needs (16). Based on (17) research finding in Malaysia, the positive correlation between labelling and purchase intention indicates that as customers have higher confident in labelling of the halal products, they will have higher intention to purchase the Halal products. Consumers who can differentiate and are confident about the genuineness of the Halal logo tend to have higher intent to purchase the products.

In Indonesia nowadays many cosmetics can be found with the halal logo, giving halal logo on cosmetics is not only apply to new brand, or brand with specific targeting to muslim consumer and claiming itself as halal cosmetic brand, but existing or even old cosmetic brands are started applying halal logo on their products, the authorized institution in Indonesia that have authorization to issue halal certification is only LPPOMMUI.

Manufactures' practice to apply halal logo on products do not necessary give them chance to the be chosen by target consumer, therefore halal logo becomes one of the variabels to be checked in this study, it is necessary to find out whether halal logo on product significantly influence consumers positive perception that eventually lead them to make a decision to purchase halal cosmetic product.

$\mathrm{H} 2$ : There is significant relationship between halal logo and positive perception

\subsection{Halal Marketing Package}

Regards to the raising of halal cosmetics, cosmetic brand must be smart to take the heart of the target consumer or simply convince consumers about their product, regardless of the condition that the product may already have halal logo or not yet applied halal logo, consumers need to know whether the product impressed halal in their perception, one way to do is to package the brand communication into halal marketing package.

The study of the effect of halal marketing package is also important for cosmetic brand to be able to find out whether this halal marketing package can be a means of forming positive perception of consumers, moreover if the brand comes from a conventional brand or non dedicated halal cosmetic brand, will this non dedicated halal cosmetic can be accepted in the hearts of consumers regards to halal concern issues.

According to (18) The Muslim market is halal-conscious and discerning as they search for information determining whether the product is halal or not, therefore the action to create positive perception and halal perception is considered important to be competitive in cosmetic market in Indonesia.

In this study halal marketing package is divided based on 2 dimensions, first dimension is the role of a muslimah model, a female endorser with Muslim fashion or hijab and $2^{\text {nd }}$ dimension is halal message in communication content.

According to (19) based on his study in Middle East Islamic terminology may be used in advertisements to reassure consumers of the Islamic integrity of products and services. He gives example about a television advertisement, a Saudi investment bank in Egypt used religious terms to show that it did not deal in any Islamically unlawful financial products. The use of selected Qur'anic injunctions and words can enhance the mood of the advertising communication to make it more appealing to Muslim consumers. For Examples are the words "Bismillah" (in the name of God; a phrase used by Muslims before beginning any action) or "Allahu akbar" (literally, God is greater)
One of the other packages of marketing packages is the use of a veiled woman model or model with hijab to create polite impression, maintain courtesy and fit the target Muslim women. Referring to (20). The noble depiction of women in Islamic advertising should be carried out without the use of the sex appeal. Women need to have greater privacy with regards to the covering of their bosom and dressing modestly due to the differences of their 'nature, temperaments, and social life'; the acts of purity contribute to holiness in this provisional life as the real success is aimed for in the spiritual endeavour (The Holy Qur'an: English translation of the meanings and commentary, n.d.). Advertisers should portray Muslims talents in an Islamic manner in terms of dress and roles. According to (21) Endorser is supporting advertising or also known as commercials in favor of pro advertising support.

$\mathrm{H} 3$ : There is significant relationship between halal marketing package and positive perception

\subsection{Positive Perception}

Positive halal perception begins with the collection of information from the environment. The information obtained is then interpreted by the consumer. This process of interpretation requires acceptance of information and includes two cognitive processes of attention and comprehension. In the consumer attention process choose which information is needed, then the consumer comprehension process determines the subjective meaning that creates knowledge and belief (beliefs). This knowledge and beliefs are stored in the memory and can be "called back" at any time in the future. At the integration stage, consumers combine the knowledge and feelings of the product or brand to create attitudes and intentions that are the trigger factors of a behavior. Consumers who have the same affiliation will share the same cognitive system (22).

Positive halal perception becomes the mediating variable among halal logo, beauty blogger and conventional halal marketing package with purchase decision in halal cosmetic.

$\mathrm{H} 4$ : There is significant relationship between halal positive perception and purchase decision

\subsection{Purchase Decision}

According to Kotler, Armstrong has four main factors that influence consumer buyer behavior (23) Consumer purchasing behavior is influenced by four main characteristics of buyers: cultural, social, personal, and psychological. While many of these factors can not be influenced by marketers, it can be useful for identifying interested buyers and in shaping products and appeal to better serve consumer needs.

Referring to the journal written by (24) Consumer behavior and consumer purchase behavior in accordance with the confirmation of his request. Therefore, in this study the following two elements are used:

1. The purpose of information retrieval: summarizing consumer behavior and buying behavior based on references from (25) (26), when the consumer confirms his request, he will start looking for information relevant. That means consumers read about relevant product information through various sources, compare differences between products, and then spend more time on product searches (27). In this process when consumers buy a product, the intention of information retrieval takes a large portion. Therefore, the desire to search information as the first element in influencing consumer purchasing decisions.

2. Buying desire: in evaluating alternatives and decision-making decision maps, (28) suggest that between alternative evaluations and purchasing decisions, both will shape the desire to buy. (8) verify that buying desire can be considered an important index for predicting consumer behavior. Therefore, this study selects the buying desire as a second element influencing consumer purchasing decisions. 


\section{Methodology}

The approach used is a quantitative model and this research is conducted via on-line survey through Whatsapp mobile application, target respondents are women age range between $20-50$ years old who are familiar exposed to the and having a social media account, located in DKI Jakarta and Surabaya. Jakarta is chosen as a capital city of Indonesia while Surabaya is chosen to present east Indonesia major city.

This research model has five latent variables. The collection of data to see relationships between latent variables using a questionnaire five-point Likert scale where (1) for the selection of "Strongly Disagree" to (5) "Strongly Agree". As for the demographic questions using multiple choice. The indicator questions or variable measurements in this study was adapted from several sources.

Questionnaires distributed to 100 female respondents combined between muslim and non-muslim respondents with the criteria of the respondents as follows: they are in active age group 20 up to 50 years old, use or have ever used cosmetic brand regular product or mass-market brand, brand decision maker, SES and education levels are free (not restricted), questionnaires filled by respondents themselves (self-administered questionnaire) through on-line survey.

To determine the sample size for quantitative research, according to Robin Hill (29) in the journal titled "What Sample Size is "Enough" in Internet Survey Research?", he mentioned that according to (30) in behavioral research, sample larger than 30 is ensure the researcher the benefit of central limit theorem while a samples of 500 assure that sample error will not exceed $10 \%$ of standard deviation about $98 \%$ time. Thus the range of 30-500 for sample size is appropriate for a study. In this research, the respondent collected for quantitative research is 76 persons with simple random sampling as all kind of respondents, as long as they use mass-market cosmetic brands, they have equal opportunity to participate in this survey.

\section{Result and Findings}

This study has gathered 62 respondents from total 100 target respondents, on-line survey was conducted by using structural questionnaire, up loaded digitally by using Google forms, that been delivered by using smartphone through WhatsApp mobile application within 1 week of field study from $5^{\text {th }}$ August to $11^{\text {th }}$ August 2017. This study is conducted in Jakarta and Surabaya. All questionnaires were evaluated using a five-point likert scale, where higher score represent agreement, while lower score represent disagreement. Respondent's demographic's were analysed separately from the primary model.

From respondents side it is revealed if respondents are mostly comes from young age generation $64 \%$ from ages range $20-30$ years old , 60\% are graduated from senior high school and 69\% are muslim. After first modification, all returned answers were analysed using SmartPLS 3.0 Software.

The results of reliability and validity tests indicate several items with loading factors lower than 0.7 were removed, and the analysis was performed once again. The second analysis results revealed that the remaining item's outer loadings exceed 0.7 which indicates if indicator variabels are acceptable.

According to (31) suggested value 0.70 and 0.9 should be desirable in advance stages of research. Results of the cronbach's $\alpha$ are also as expected. PLS-SEM prioritizes the indicators according to their individual reliability, and cronbach's $\alpha$ assumes that all indicators are equally reliable. According to (32) cronbach's $\alpha$ measures of reliability that ranges from 0 to 1 , with values of 0.6 to 0.7 deemed the lower limit of acceptability.

In this findings shown that all latent variabels get cronbach's $\alpha>$ 0.8 . Looking at the average variance extracted (AVE), results of convergent validity for each latent variable are also greater than the acceptable threshold of 0.5 (33). As a parameter, this indicates that the degree to which measures of contructs that theoretically should be related, are in fact related.

Analysis of discriminat validity is used to measure the validity and reliability of the model, in this section it can be seen that the relationship between itself for each latent variable is stronger than its relationship with other latent variables, it indicates that the latent variable is strong enough with itself and the indicator is also supported.

The Path coefficiet among constructs shown all positive relationship, where halal marketing package path coefficient value 0.492 has strongest positive relationship to positive perception, path coefficient value 0.903 from positive perception to purchase decision shown if positive perception has the most significant relationship to create purchase decision.

From 3 endogenous latent variable, resulting R2 value more than 0.7 , Purchase decision $\mathrm{R} 2$ value 0.816 shown high predictive accuracy from positive perception. $\mathrm{R}^{2} 1.0$ for Halal marketing package shown if there is no error variance and $100 \%$ of the construct is explained by the indicator. $\mathrm{R} 2$ Value ranges from 0 to 1 , with higher level indicating higher level of predictive accuracy. R2 value 0.2 are considered high in consumer behavior study. In scholary research focus in marketing $\mathrm{R} 2$ value $0.75,0.5$ or 0.25 still acceptable (34).

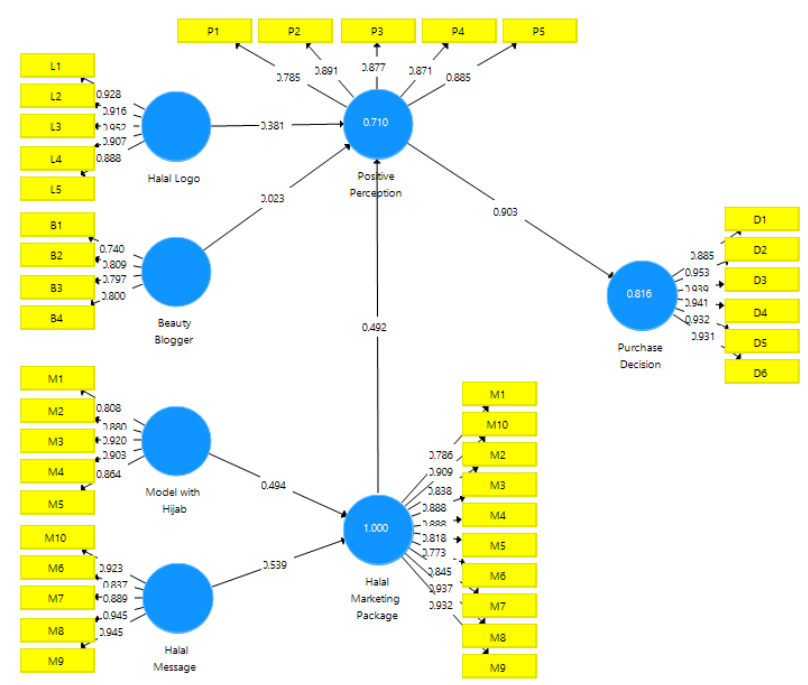

Figure1: Structural Graph after Data Processing Source: SmartPLS Software data processing

\section{Conclusion}

The results of this study indicate if positive perception clearly and strongly indicate relationship to purchase decision, based on this study halal marketing package gives the most significant relationship to create positive perception on halal cosmetic, Beauty blogger which is suspected significant to create positive perception only has a low coefficient path value of 0.023 which is considered to be very weak or almost no significant, however the outer loading for each indicator is relatively high value of $>0.7$ and consider valuable to be used for further study. Halal logo has positive relationship with positive perception with path coefficient value of 0.381 is consider moderate to form a relationship with positive perception.

Based on the results of this study, the authors suggest to cosmetics companies in Indonesia to use halal marketing package via brand communication to create positive perception about brand in order to influence target consumer of halal cosmetic products, halal marketing package is significantly has positive relation more than halal logo and beauty blogger, halal marketing package such as model with hijab and halal message are proven based on this study to create positive perception about halal cosmetic product and 
eventually support consumer decision to purchase halal cosmetic product. While cosmetic manufacturer still can use the advantage of halal logo on the product as complementary aspects to strengthening consumer positive perception.

\section{References}

[1] Technavio. HALAL COSMETICS AND PERSONAL CARE MARKET IN THE APAC REGION 2014-2018 [Internet]. 2014 Available from: http://www.technavio.com/report/halal-cosmeticsand-personal-care-market-in-the-apac-region-2014-2018

[2] Pew Research Center. The future of the global Muslim population. Projections for 2010-2030. Popul Sp Place. 2011;13(1):1-221.

[3] Lada S, Tanakinjal GH, Amin H. Predicting intention to choose $\langle\mathrm{IT}>$ halal $</ \mathrm{IT}>$ products using theory of reasoned action. Int $\mathrm{J}$ Islam Middle East Financ Manag. 2009;2(1):66-76.

[4] Wilson JAJ, Grant J. Islamic marketing - a challenger to the classical marketing canon? J Islam Mark [Internet]. 2013;4(1):7-21. Available from: http://www.emeraldinsight.com/doi/10.1108/17590831311306327

[5] Techinasia. https://www.techinasia.com/indonesia-web-mobilestatistics-we-are-social.

[6] Kempe D, Kleinberg J, Tardos É. Maximizing the spread of influence through a social network. Kdd [Internet]. 2003;137. Available http://portal.acm.org/citation.cfm?doid=956750.956769

[7] Zhan J, Loh HT, Liu Y. Gather customer concerns from online product reviews - A text summarization approach. Expert Syst Appl [Internet]. 2009;36(2 PART 1):2107-15. Available from: http://dx.doi.org/10.1016/j.eswa.2007.12.039

[8] Fishbein M, Ajzen I. Belief, Attitude, Intention, and Behavior: An Introduction to Theory and Research [Internet]. Reading, MA: Addison-Wesley. 1975. p. 1-18. Available from: http://home.comcast.net/ icek.aizen/book/ch1.pdf

[9] Ajzen I, Madden TJ. Prediction of goal-directed behavior: Attitudes, intentions, and perceived behavioral control. J Exp Soc Psychol. 1986;22(5):453-74.

[10] Ajzen I. Ajzen, I. (1991). The theory of planned behavior. Organizational Behavior and Human Decision Processes.The theory of planned behavior. Vol. 50, Organizational Behavior and Human Decision Processes. 1991. p. 179-211.

[11] Hennig-Thurau T, Gwinner KP, Walsh G, Gremler DD. Electronic word-of-mouth via consumer-opinion platforms: What motivates consumers to articulate themselves on the Internet? J Interact Mark. 2004:18(1):38-52.

[12] Wilson JAJ, Belk RW, Gary JB, Sandikci Ö, Kartajaya H, Sobh R, et al. Crescent marketing, Muslim geographies and brand Islam: reflections from the JIMA Senior Advisory Board. Vol. 4, Journal of Islamic Marketing. 2013. 22-50 p.

[13] Balakrishnan BKPD, Dahnil MI, Yi WJ. The Impact of Social Media Marketing Medium toward Purchase Intention and Brand Loyalty among Generation Y. Procedia - Soc Behav Sci [Internet]. 2014;148:177-85. Available from: http://www.sciencedirect.com/science/article/pii/S18770428140393 66

[14] Kozinets R V., Valck K, Wojnicki AC, Wilner SJ. Networked Narratives. Underst Word-of-Mouth Mark Online Communities. 2010;74(2):71-89.

[15] Chaovalit P. Factors influencing cosmetics purchase intention in Thailand : a study on the relationship of credibility and reputation with the persuasive capabilities of beauty bloggers. AU-GSB eJournal. 2014; Vol. 7(1):34-42.

[16] Abdul J, Shaari N, Shahira N. Dimension of Halal Purchase Intention: A Preliminary Study Shaari \& Arifin. Int Rev Bus Res Pap. 2010;6(4):444-56.

[17] 17. Hussin SR, Hashim H, Yusof RN, Alias NN. Relationship between product factors, advertising, and purchase intention of Halal cosmetic. Pertanika J Soc Sci Humanit. 2013;21(SPEC. ISSUE):85-100.

[18] A.J Wilson \& Jonathan Liu. The challenges of Islamic branding: navigating emotions and halal. 2011;

[19] Rice. The Implications of Islam for Advertising Messages: The Middle Eastern Context. 2002;

[20] Kassem, S., \& St. John D. Sex in Advertising: Its Relevance, Use, and Effects. Management Decision, 11(3), 145-158. 1973.

[21] Shimp T. Advertising, Promotion and Other Aspects of Integrated Marketing Communications. 2003;
[22] Mokhlis S. The effect of religiosity on shopping orientation: An exploratory study in Malaysia. J Am Acad Bus. 2006;9(1):64-74.

[23] Philip Kotler GMA. Prentice Hall. Prentice Hall; 2005.

[24] Lin L, Chen C. The influence of the country-of-origin image , product knowledge and product involvement on consumer purchase decisions : an empirical study of insurance and catering services in Taiwan. 2006;

[25] Nicosia FM. Consumer Decision Process, Marketing and Advertising Implication,. Prentice-Hall, Englewood Cliffs, NJ,; 1968. p. 156.

[26] Howard JA (1989). Consumer Behavior in Marketing Strategy. Prentice-Hall, Englewood Cliffs, NJ.; 1989.

[27] McQuarrie, E.F. and Muson JM. "The Zaichkowsky personal involvement inventory: modification and extension", in Wallendorf, M. and Anderson, P. (Eds), Advances in Consumer Research, Vol. 14, Association for Consumer Research, Provo, UT. 1992. pp 33-40

[28] Kotler, P., Ang, S.H., Leong, S.M. and Tan C. A Marketing Management, Asian Perspective, 2nd ed. Prentice-Hall, Englewood Cliffs, NJ.; 1999.

[29] Hill R. WHAT SAMPLE SIZE is " ENOUGH" in INTERNET SURVEY RESEARCH? nterpersonal Comput Technol An Electron J 21st Century. 1998;6(3):1-10.

[30] John T. Roscoe. Fundamental Research Statistics for the Behavioral Sciences (International series in decision processes). 1979.

[31] Nunnally, J.C. \& B. Psychometric Theory. Vol. 3. McGraw Hill, New York; 1994.

[32] HAir Jr, Black, Babin A. Multivariate Data Analysis. Pearson/Prentice Hall; 2014.

[33] Bagozzi RP, Yi Y. On the Evaluation of Structural Equation Models. Vol. 16, Journal of the Academy of Marketing Science. 1988. p. 74-94.

[34] Hair, J.F., Ringle, C.M., Sarstedt M. PLS-SEM: indeed a silver bullet. J Mark Theory Pract 19 (2), 139-151. 2011; 